\title{
Claridade: movimento de emancipação cultural e ideológica cabo-verdianas
}

\section{Alberto Carvalho}

Centro de História da Faculdade de Letras

Universidade de Lisboa

- alberto.adcarvalho@gmail.com

URL www.literatura-no-sitio.pt/wp/

Dol https://doi.org/10.34913/

journals/lingualugar.2021.e525 
A revista Claridade, de periodicidade descontínua, compreende nove números distribuídos por três ciclos, 1936-1937, 1947-1949, 1958-1960, representando na história literária cabo-verdiana o estabelecimento do período realista, sucedente ao primeiro período, romântico, iniciado na segunda metade do século XIX.

Quando ao seu ideologema (na nossa interpretação: Cabo Verde caboverdiano) pode-se dizer, simplificando os dados, que se escande segundo aqueles três ciclos: o primeiro de afirmação identitária, o segundo de diálogo exógeno e o terceiro motivado pela reivindicação nacionalista em situação de país submetido ao regime colonial.

Palavras-chave: Cabo Verde; Claridade; identidade; nacional; nacionalismo.

La revue Claridade, à périodicité intermittente, comprend neuf numéros répartis sur trois cycles, 1936-1937, 1947-1949, 1958-1960, représentant, dans I'histoire littéraire capverdienne, l'instaura-tion de la période réaliste, suivant à la première période romantique de la seconde moitié du XIXe siècle.

Concernant son idéologème (dans notre interprétation, le Cap-Vert cap-verdien), on peut dire, en simplifiant les données, qu'il s'élargit selon trois cycles: le premier d'affirmation identitaire, le se-cond de dialogue exogène et le troisième motivé par la revendication nationaliste dans un pays soumis au régime colonial.

Mots-clés: Cap-Vert; Claridade; identité; nationale; nationalisme. 
Um texto de M. Merleau-Ponty servir-me-á de ilustração. Fazendo valer dois modelos temporais opostos ligados um à prática do fotógrafo, o outro à do pintor, lembra-nos que temos a escolha entre contínuo e descontínuo [...]. Jean-Claude Coquet ${ }^{1}$

\section{Estudos sobre Claridade}

Mostra a grande soma de dados empíricos que, para além de umas quantas críticas de motivação ideológica, ${ }^{\mathbf{2}}$ nenhum movimento literário cabo-verdiano despertou interesse idêntico ao da Claridade. Ao longo de décadas tem-se confirmado a sua consagração por uma apreciável diversidade de trabalhos e de colóquios dedicados ao seu estudo que não perdem de vista a circunstância de ter constituído um fenómeno de todo inesperado num pequeno país sob domínio colonial, paciente de gritante carência de recursos naturais e sempre sob a contingência do flagelo cíclico de secas catastróficas.

A despeito do tempo entretanto decorrido, ainda há poucos anos uma série de oito trabalhos de assuntos muito diversos rendeu homenagem ao movimento representado pela revista, num volume cujo título conota o seu estatuto de nobreza em termos de linguística histórica. Com o rodar dos anos o nome próprio, "Claridade", engendrou o seu adjectivo de qualidade, "claridosos" (atribuído aos autores alinhados pelo espírito da revista) que entretanto suscitaria o nome abstracto, "claridosidade", para conferir substância identitária à estética da revista no interior da periodologia literária cabo-verdiana. ${ }^{3}$

Tal número de ensaios a ela dedicados, ao perfil estético dos autores fundadores, à originalidade revelada, à questão da influência eventualmente recebida, à finitude ou não do ideário programático no contexto

1

1 Un texte de M. Merleau-Ponty me servira d'illustration. En faisant valoir deux modes temporels opposés liés I'un à la pratique du photographe, l'autre à celle du peintre, il nous rappelle que nous avons le choix entre continu et discontinu [...] (tradução nossa, Coquet, 1997, p. 57).

2 e Africanidade", Vértice, n. 134, Coimbra, pp. 639-644. [Republ. (1999). Caboverdianidade e Africanidade e outros Textos. Praia: Spleen, pp.23-29]. Silveira, O. (1963). Consciencialização na Literatura Cabo-Verdiana. Lisboa: CEI, pp. 7-30.

3 AA.VV. (2017). Claridosidade, Edição Crítica. Lisboa: Rosa de Porcelana. 
das ideologias nas décadas de 1930-1970, relevam de uma pregnância que incita a uma abordagem orientada para a problematização dos factos, das circunstâncias e das motivações de vários não-ditos e silêncios no que, concretamente, respeita aos meandros do seu protagonismo nesses tempos históricos exaltantes, literários, ideológicos e políticos, bem determinados.

\section{Ausência de Programa, objectivos implícitos}

Posta a revista em circulação sem aparato de apresentação e sem um enunciado de ideias programáticas, tal facto deve ser interpretado como decisão intencionada, eventualmente de auto-defesa, mas também de sentidos que assim se podem resumir: i) Ostentação, para que constasse, da identidade diferenciada, crioula, reivindicada com convicção tão segura que não carecia de justificação perante o Portugal colonizador, ou mesmo o Brasil, país de história colonial ligada a Cabo Verde, de similar identidade geográfica tropical e de onde os escritores de Claridade poderiam extrair sugestões úteis à representação dos problemas que Ihes tocavam; ii) E, talvez, deixar em aberto as condições de acolhimento de autores de gerações futuras, motivadas pelas questões que se avizinhavam na Europa e em outras partes do mundo.

Este objectivo, criar as condições necessárias para a integração de novos autores, pode ser visto como motivação inconsciente, vivenciada, inscrita no seu rico histórico geracional, afim do conceito de intelectual orgânico da teoria materialista gramsciana, conceito que se elucida numa breve resenha sobre a história geral de Cabo Verde.

\section{Precedente histórico do elitismo}

As fontes documentais ${ }^{4}$ referem o facto de a comunidade cabo-verdiana ter iniciado a sua organização sob o regime colonial escravocrata e sob o seu sistema vivido até uma grande parte do século XIX, largamente reequilibrado pelas influências da Igreja de proselitismo evangelizador que, no início do século XVI, começaria por criar na povoação da Ribeira Grande uma escola de ladinização de escravos ${ }^{\mathbf{5}} \mathrm{e}$, mais tarde, uma Escola de preparação de missionários.

Graças à política de evangelização chegava-se à naturalização do conceito de Escola, tornando familiares as

\footnotetext{
4 Cf., nomeadamente, Carreira, A. (1983). Cabo Verde - Formação e Extinção de uma Sociedade Escravocrata (1460-1878), s.I., ICL.

5 Os escravos ladinizados pela escola de Sacristia, apetrechados com rudimentos de escolaridade, convertidos ao catolicismo e com nome português, seriam depois, no Brasil, escravos de dentro (de casa). Esta escola prestavase igualmente à instrução dos filhos das elites residentes, devendo-se ainda notar o facto de os escravos acompanhantes dos filhos das elites aproveitarem a ocasião para também se escolarizarem, tópico da maior importância sociológica no que respeita à produção e difusão do gosto e da tomada de consciência da necessidade da instrução escolar. Cf. Carreira, A. (1983). Cabo Verde - Formação e Extinção de uma Sociedade Escravocrata (1460-1878), s.l., ICL.
} 
ideias de ensino e de instrução, antes de tudo o mais, como meio de libertação da difícil vida agrícola e de acesso a empregos remunerados e prestigiantes, por exemplo, nas Alfândegas, nas actividades comerciais e na Administração colonial. Aliás, a instrução escolar como forma de promoção pessoal, social e económica reflectia-se ainda nos tempos de Claridade:

Para mim ia abrir-se uma nova vida. No ano-lectivo seguinte eu seria matriculado no curso do liceu, no Seminário [de S. Nicolau]. Com a boa cabeça que Deus lhe tinha dado, seria pena que Chiquinho ficasse a lombar na enxada. A escola esperava-me de braços abertos para me conceder a carta de alforria [Trabalho da terra como "escravatura"]. Assim, mais tarde eu poderia falar de alto para aqueles que apenas tinham feito o $2^{\circ} \mathrm{grau}$ (Lopes, 1947, p. 72).

No eixo isotópico que insere a ordem da instrução num mundo de dominância oral, seriam bem mais tarde as ideias liberais do século XIX que impulsionariam a fundação do prelo oficial (24/8/1842), a abertura de uma escola secundária (1848) e, a partir de 1850, a emergência de numerosas associações de cultura e recreio e de bibliotecas e, sobretudo, a fundação de um Seminário-Lyceu na ilha de S. Nicolau (1866).

Chegava-se assim à criação das condições objectivas necessárias à emergência do sistema da escrita, inicialmente pragmática, condição ainda para a criação de um horizonte de leitura que, como mostram os estudos de Roberto Escarpit (ILTAM, Universidade de Bordéus), era um dos pressupostos para a eclosão da escrita literária na segunda metade do século XIX na poesia de mulheres e homens, de formação inicial em Lisboa e depois, em grande parte, no Seminário-Lyceu de S. Nicolau.

Aliás, cerca de 1860-1870, os conteúdos da consciência autárquica já atingiam a fase de consolidação, mas de maneira muito singular. De um lado, as gentes do povo viviam, sem se aperceberem, o sentimento de nação, de identidade étnica e cultural, de destino e de passado histórico comum, tudo simbolizado pela língua crioula. Do outro, pertencia às elites, aos poetas, trabalharem esses genuínos sentimentos nacionais em formas de escrita literária e de os conceptualizarem nos sentidos da individualidade e da entidade crioulas, funções que se podem admitir próprias da estética e da poética românticas. ${ }^{6}$

\footnotetext{
6 As ideias apresentadas neste parágrafo são desenvolvidas em Carvalho, A. (2017). "Da Claridade, ainda, e sempre". In: AA.VV. Claridosidade, Edição Crítica. Lisboa: Rosa de Porcelana, pp. 17-39.
} 
De muito apuro literário, este romantismo, não raro ultra-romântico, impregnado de elementos de estilo clássico, simbolista, parnasiano, alongar-se-ia pelas duas primeiras décadas do século XX. (Insista-se no facto anacrónico de, em Cabo Verde, o romantismo ter precedido o classicismo, uma vez que o humanismo clássico difundido pelo Seminário-Lyceu inspirava uma nova orientação estética, no último quartel do século XIX, ao tempo em que o romantismo vinha sendo cultivado havia cerca de duas décadas). ${ }^{7}$

Entre o início do século vinte e a década de 1930 acentuara-se o diferencial entre as duas séries postas em confronto. ${ }^{8}$ A série literária perdia protagonismo por esgotamento da sua necessidade cultural em proveito da séria social jornalística que ia ganhando terreno, dinamizada por razões ideológicas e pelo facto inevitável de o Seminário-Lyceu, foco de humanidades e de saberes eruditos muito elaborados, ter sido despromovido cerca de 1911 e encerrado em 1918 por efeito das políticas que, nesta mesma data, levaram à fundação do Liceu de Mindelo.

Este novo centro de estudos laicos e democráticos permitia que todos os estudantes preservassem os laços com os espaços de origem com os quais se identificavam, estado de coisas escolares e sociais que favorecia a súbita reactivação da série literária, mas agora orientada para uma estética de matriz realista. (Ver-se-á que a partir da Alínea "Oposição de termos irredutíveis" o activismo da série literária absorveu parte da série social).

\section{Antigos VS Modernos, Elitistas VS Democráticos}

Nas décadas de 1920-1930, as condições objectivas incrementadas pelo Liceu de Mindelo despoletavam agora um conflito geracional. Embora esgotada a legitimidade humanista e elitista da série literária romântica-clássica, os seus poetas esforçavam-se por conservar o espaço social dos valores estéticos em que se formaram, como mostra a reacção de Pedro Cardoso (1890-1942), um poeta desta escola:

7 Existem diferentes propostas para a divisão periodológica da literatura caboverdiana. No nosso caso guiamo-nos por algumas das teses de Lucien Goldmann (Pour une Sociologie du Roman, 1964), segundo o qual um período literário se define pela substância ética autoral, valores que definem o seu ideal de vida e pela sua concretização ética no plano estético, no objecto da obra literária. A ética e a estética constituem assim as duas faces de uma mesma moeda. Nada impede que num determinado período convivam duas ou mais estéticas, sendo porém certo que é a estética dominante que dá nome ao período (por exemplo, dentro da estética nomeada realista, inaugurada pelo movimento Claridade, compareciam a estética clássica de Pedro Cardoso, a simbolista de José Lopes, a préromântica e, ao mesmo tempo parnasiana de Januário Leite, restos subsistentes que, a meu ver, em vez de abstrusos, só enriquecem, pela diversidade, uma cena literária). Assim, considero quatro períodos na literatura cabo-verdiana: o período romântico de meados do século XIX até finais da década de 1920; o período realista, iniciado na década de 1930 simbolicamente representado pela revista Claridade, prolongando-se até ao início da década de 1960; o terceiro período subsiste da década de 1960 até meados da década de 1980, durante os tempos da luta nacional, caracterizando-se pela grande diversidade de intenções autorais, mas cingidas à mesma intencionalidade soberanista, podendo surgir etiquetas como poesia da clandestinidade, da militância, de panfletismo, de mobilização, de incitamento (entre outras designações), intencionalidade animada por uma idêntica visão ética do mundo e por uma expressão estética configurada numa enunciação de "nós" inclusivo (Cf. Benveniste sobre a instância da enunciação), "nós" comunitário, que acabará por ser movido pela expressão textual do ideal soberanista, primeiro, entre a década de 1960 e meados da de 1970, pela vivência da luta e, entre meados da década de 1970 e início da de 1980, pela vivência encantatória da soberania finalmente adquirida. Podemos dizer que neste período a expressão literária (estética, portanto) de função 
A convivência de amigos, literatos de verdade, e a frequência diurna e nocturna dos mestres mudos, deram foros de vocação ao que suponho a mera resultante da educação puramente humanista recebida [...]. Apesar, ou por causa do meu classicismo ortodoxo, serão sempre perentórios e extremos os meus juízos: gosto ou não gosto, que os gostos não se discutem (Cardoso, 1934, p. 9). ${ }^{\mathbf{9}}$

A réplica muito agressiva proveio do novo Quirino Spencer Salomão em nome das ideias literárias modernas, agora libertas das regras académicas da poesia em forma fixa. Evoca para a função poética a "necessidade de exprimir a vida interior" e para as formas textuais uma "operação [...] obtida através da estilização". Citando João Gaspar Simões, intelectual da revista portuguesa Presença, pretende que a poesia seja a "transposição do plano [...] vital para o estético, dos fenómenos psicológicos (apud Ferreira, 1986, p. LVIII).

Negligenciando as ideias ingénuas do jovem crítico, filiadas na estética psicologista, oposta aliás à estética realista por si apologizada para Claridade, diremos que tal conflito simboliza, no plano sincrónico, a querela geracional dita "Antigos VS Modernos". Com toda a inocência, rasurava a diacronia do primeiro período histórico-literário romântico (cerca de 1850-1930), responsável pelo conceito identitário de que estes novos tiravam o melhor partido possível.

Sem programa e sem uma estética de limites definidos, os modernos de Claridade iriam alicerçar a afirmação identitária na estética da contemporaneidade realista, em condições ideológicas muito perturbadas que incluíam a Europa interpelada pela Negritude parisiense e pelas guerras que se avizinhavam. (Sublinhe-se: o lançamento de Claridade, isolada no Arquipélago atlântico, é contemporâneo da eclosão da Negritude, em Paris).

Por ironia, mostram as idades de João Lopes (1894-1979) e de Jaime de Figueiredo (1905-1974) o valor operativo dos precursores (literatos e jornalistas) ao protagonizarem, na década de 1920 e início da década de 1930, as condições de emergência de Claridade, sensivelmente ocasião que contava com a presença, em Cabo Verde, de três intelectuais portugueses, Julião Quintinha, José Osório de Oliveira e António Pedro (notável homem do teatro nascido em Cabo Verde). 
No respeitante à perplexidade suscitada em Portugal e no Brasil pelo alto gabarito revelado pela revista Claridade, oriunda daquela territorialidade tão castigada, devem-se ter em conta duas ideias gerais de amarga tonalidade irónica:

Falho de condições próprias que poderiam tornar rentável a exploração de um território geograficamente limitado e pequeno, o arquipélago, se por um lado ganhou o justo epíteto de terra de fome, por outro, pela ausência dessas mesmas condições favoráveis, tornou-se o cadinho de uma rica experiência social (França, 1962, p. 7).

\begin{abstract}
A tendência destes meios [pequenos] é de extravasarem "todos" os seus limites ou "parte" dos seus limites, consoante as possibilidades económicas forem satisfatórias ou modestas. Neste último caso socorrem-se do capital humano - procuram obter pelo prestígio do espírito, em compensação, o que não conseguiram por processos persuasórios ou materiais [...]. O espírito do homem superou-o (Lopes, 1959, p. 7).
\end{abstract}

Ainda sobre a Escola como forma de ilustração e de promoção social, económica e cultural, notemos que ser "posto na prenda", na formação democrática no Seminário de S. Nicolau (depois da despromoção de 1911) ou no Liceu de Mindelo, que permitia aos estudantes conservarem os laços com os meios de origem e se compaginava com a estética realista, ${ }^{\mathbf{1 0}}$ também predispunha para a assunção de formas de afirmação nacional e empenhamento nacionalista. Nos implícitos do movimento Claridade teriam de constar também as restrições impostas pela situação colonial e pela censura decor-

10 Ver a esse respeito Carvalho, A. (2017) "Da Claridade, ainda, e sempre". In: AA.VV. Claridosidade, Edição Crítica. Lisboa: Rosa de Porcelana, pp. 17- 39 e Lopes, B. (1956). Cabo Verde visto por Gilberto Freyre. Praia: Imprensa Nacional, pp. 5-6. rente do Acto Colonial de 1930-1935, tópicos que se esclarecem com a citação seguinte de Baltasar Lopes:

Tínhamos de intervir. Mas, na óbvia impossibilidade de emprego de meios de acção directa, que opção nos restava [...]. De aí o nascimento da revista Claridade [...]. Justamente essa militância [...] marcava já o programa do grupo e o conteúdo da revista. Seria "fincar os pés na terra", para empregar a expressão consagrada: um debruçar ansioso e atento sobre os problemas vitais de Cabo Verde (apud Ferreira, 1986, pp. XIII-XIV).

\title{
Os três ciclos de Claridade
}

Por razões objectivas que decorrem do regime de publicação de Claridade, costuma-se ordená-la em três ciclos ou séries: $1^{\circ}$ ciclo: $n^{\circ} 1$ (Março, 1936); $n^{\circ} 2$ (Agosto, 1936); no 3 (Março, 1937). $2^{\circ}$ ciclo: $n^{\circ} 4$ (Janeiro, 1947); $n^{\circ}$ 5 (Setembro, 1947); n० 6 (Julho, 1948); n० 7 (Dezembro, 1949). $3^{\circ}$ ciclo: no 8 (Maio, 1958); n० 9 (Dezembro, 1960). Outro dado de interesse material 
reporta-se aos índices de colaboração muito diversos nos três ciclos: No $1^{\circ}$, respectivamente, $10,10,10$ páginas; no $2^{\circ}$, respectivamente, 40 , $44,42,52$ páginas e, no $3^{\circ}$, respectivamente, 76,84 páginas.

Sublinhe-se ainda que a coordenação da revista nunca forneceu explicações, nem para as interrupções, nem para as retomas de publicação, salvo na última página do $n^{\circ} 8$, na retoma do $3^{\circ}$ ciclo, onde refere o facto de terem saído recentemente do liceu oito jovens que prometiam boa colaboração na revista.

Esta explicação, em 1958, evoca duas questões essenciais. A mais evidente consiste em confirmar aquilo a que se aludiu mais acima. Ao ter surgido sem programa na altura do lançamento, a revista propiciava a abertura à diversidade de colaborações futuras movidas por novos interesses e gostos epocais. Ora, a ideia de diversidade futura tem de pressupor um princípio de unidade entre os membros fundadores, assim testemunhado:

Há um pouco mais de vinte anos, eu e um grupo reduzido de amigos começámos a pensar no nosso problema, isto é, no problema de Cabo Verde [...]. Precisávamos de certezas sistemáticas, que só nos podiam vir [...] de outras latitudes [...]. Ora aconteceu que por aquelas alturas nos caíram nas mãos [...] alguns livros que considerámos essenciais pró domo nostra. Na ficção, o José Lins do Rego do "Menino de Engenho" e do "Banguê" [...] em poesia foi um "alumbramento" a "Evocação do Recife", de Manuel Bandeira, que, salvo um ou outro pormenor, eu visualizava, com as suas figuras dramáticas, na minha Vila da Ribeira Brava, o Jorge Amado do "Jubiabá" e do "Mar Morto" (Lopes, 1956, p. 5).

Proferido em 1956, o "Há um pouco mais de vinte anos" reporta-se aos primeiros anos da década de 1930 de germinação de Claridade, com o "alumbramento" a traduzir a ideia de descoberta. Em situações homólogas, mas desfasadas, podia a literatura brasileira sugerir aos autores da literatura cabo-verdiana um elenco de substâncias temáticas para enchimento do lema (cunhado por Manuel Lopes), "fincar os pés na terra", equivalente a enraizamento na mãe-terra.

Mesmo provisoriamente, pode-se admitir que a poesia de fenomenologia existencial urbana de Jorge Barbosa (1902-1971), a poesia essencialista de Pedro Corsino Azevedo (1905-1942), a narrativa de telurismo etno-rural de Baltasar Lopes (1907-1989) e a poesia e narrativa social de Manuel Lopes (1907-2005) satisfaziam o essencial das necessidades de Claridade do $1^{\circ}$ ciclo que escrutinava o ideário identificador da entidade civilizacional cabo-verdiana. 
São elucidativas as páginas de rosto dos três números do $1^{\circ}$ ciclo, conotadoras da afirmação desafiadora da autoridade. Desconcertando a hegemonia da língua portuguesa, o no 1 apresenta três textos em crioulo, populares, de tradição oral, um do género lantuna e dois do género batuque (batuque, aliás, interditado pela autoridade colonial a pretexto de ofensa aos bons costumes). $\mathrm{O} \mathrm{n}^{\circ} 2$ expõe ainda um poema em crioulo, mas já pertencente ao género nacional, a morna, do tão festejado poeta Xavier da Cruz, conhecido pelo nome B'Leza. E o n० 3 apresenta, em português, o poema de grande efeito realista, de Manuel Lopes, desmistificador das ilusões sobre as virtudes dos espaços "míticos" da emigração, cujas vantagens económicas custavam o sacrifício das relações de solidariedade cultivadas na mãe-terra cabo-verdiana (Poema que merece ser tomado por genuína proclamação do anti-evasionismo).

Distinguindo-se da indagação da autenticidade crioula, da orientação endógena do primeiro ciclo, os ciclos seguintes concretizam uma orientação exógena, prevalecendo no $2^{\circ}$ ciclo a abertura poética que refracta nas ilhas as tendências ideológicas decantadas da Segunda Grande Guerra, e no $3^{\circ}$ ciclo as temáticas de teor reivindicativo, umas vigorosas, outras agressivas, mas todas animadas pelo desenvolvimento das políticas que varriam o mundo empenhadas nos processos das descolonizações.

No tocante à biografia dos três autores de mais nomeada nos alvores de Claridade, Jorge Barbosa e Manuel Lopes já se premuniam da experiência da escrita poética nas formas clássica e romântica, ao passo que Baltasar Lopes não se havia ainda estreado no fazer literário. Mas outras são as diferenças operativas. Jorge Barbosa dispunha de um curso de estudos secundários e de tempo ocupado nas actividades aduaneiras. Manuel Lopes havia seguido uma formação secundária autodidáctica, mas de tempo ainda mais ocupado na companhia telegráfica inglesa sediada em S. Vicente e algum tempo depois transferido para os Açores onde permaneceu cerca de dezasseis anos. Baltasar Lopes, ao tempo professor interino no Liceu de Mindelo, diplomara-se na Universidade de Lisboa, em Direito (1928) e em Estudos Românicos (1930), aliás, um brilhante aluno formado na escola do linguista e etnólogo, Mestre Leite de Vasconcelos.

Não custa imaginar o alcance da surpresa de Baltasar Lopes ao tomar conhecimento da literatura brasileira, que Ihe sugeria temáticas muito oportunas de iniciação nas lides literárias e domínios que punham à sua 
disposição pistas para trabalho especializado em etnografia. Admitimos serem as suas competências científicas que fornecem explicação para: i) A grande diversidade de assuntos da revista; ii) A produção teórica no domínio da linguística histórica do crioulo; iii) A publicação de histórias de tradição oral seguidas de comentários e interpretações; iv) Os trabalhos de pesquisa nos domínios da etnologia e da etnografia; v) $E$, por acréscimo, a circunstância de ser ele o único, entre os três citados, a dispor do tempo exigido pela coordenação funcional da revista.

Prova empírica desta asserção é o facto de, para progredir na carreira docente (para passar à categoria de efectivo), Baltasar Lopes ter retornado a Lisboa para concretizar o Cursos de Ciências Pedagógicas nos anos de 1838-1940, seguido de um ano escolar de docência no Liceu de Leiria no ano de 1941-1942. Não por acaso este período coincide com o primeiro interregno de Claridade que se prolonga até 1947, já em tempo de paz após a Segunda Grande Guerra, interregno durante o qual seria publicada a revista Certeza (1944).

Lançada por iniciativa dos estudantes do Liceu de Mindelo da década de 1940, esta revista recebeu a influência indirecta do escritor português Manuel Ferreira (1917-1992), expedicionário militar no Mindelo (1941-1947), que os iniciou no ideário neo-realista em vigor em Portugal. Sob tais auspícios ideológicos, a revista estava destinada a uma vida efémera, com dois números publicados (Março e Junho de 1944), logo vítima da censura que interditou a saída do terceiro número (Janeiro de 1945).

A sua particularidade inovadora consistiu em, preterindo os assuntos autóctones, ter dado prioridade a questões sociais do mundo contemporâneo, com especial relevo para o texto de Orlanda Amarílis (1924-2014) sobre a condição subalterna da mulher no mundo ocidental. ${ }^{\mathbf{1 1}}$

11 Amarílis, O. (1944). "Acerca da Mulher", Certeza n. ${ }^{\circ}$ 1, S. Vicente, Março, p. 6. 


\section{Caso de António Aurélio Gonçalves, analista da sociedade urbana}

A despeito do aparente monolitismo das influências brasileiras sobre os autores do $1^{\circ}$ ciclo de Claridade, eram diversificadas as ideias correntes na cena literária, sintomaticamente conotadas pela posição de António Aurélio Gonçalves (1901-1984). Estudante em Lisboa durante vinte e dois anos (1917-1939), "bon vivant" frequentador das tertúlias literárias e de Cursos muito diferentes (Medicina, Belas-Artes e Direito) e finalmente diplomado em História e Filosofia pela Universidade de Lisboa, declara lapidarmente, em 1960, como quem quer pôr os pontos nos ii:

A maioria acredita na solução que, frequentemente, lhe foi dada: as tais origens situam-se na descoberta de certos valores [...] da geração de escritores brasileiros [...]. Há muito de verdade [...] [nisso, mas correndo] o perigo de parecer simplista [...]. Intervieram outras determinantes mais poderosas e de raízes fundas, como, por exemplo, a convicção de uma originalidade regional cabo-verdiana [...]. O realismo nas letras de Cabo Verde é fase extrema de um caminho estirado [...]. Houve [...] um ambiente literário que principia a formar-se com a leitura dos poetas, romancistas e oradores do ultra-romantismo [...] dos parnasianos [e outros mestres] não só de Portugal e do Brasil como do estrangeiro, mormente da França (Gonçalves, 1960, pp. XXVIII-XXX).

Insistindo embora no tópico comum da identidade original de Cabo Verde, a tónica argumentativa incide na saudação das elites cabo-verdianas do século XIX (que os jovens intelectuais de Claridade combateram com denodo), considerando-as precursoras de um diálogo com as correntes estéticas orientadas para o universalismo. Também se percebe que, ao associar os sentidos endógenos da identidade cabo-verdiana à abertura exógena, estava a ser juiz em causa própria, a justificar a estética das suas narrativas dedicadas à clínica problematizadora da vida urbana mindelense e aos condicionamentos hereditários e sociais, narrativas não raro de teor naturalista, sustentadas pelas competências do filósofo conhecedor das literaturas europeias, nomeadamente a russa e a francesa.

O universalismo que o levava a transcender as temáticas cingidas à identidade étnica e à militância ideológica torna também evidente a divergência com o ideário de Baltasar Lopes (cf., "Tínhamos de intervir", "alumbramento"). E, sendo plausível que a ausência lisboeta possa ser argumento para António Aurélio Gonçalves não comparecer no $1^{\circ}$ ciclo de Claridade, o seu alheamento em relação ao ideologema identitário dominante nesses três números poderá ser inferido do ensaio puro e duro, "'Clarissa' e a arte de contar de Erico Veríssimo - I" (Gonçalves, 1947, 
pp. 26-36) publicado no $\mathrm{n}^{\circ} 4$ de Claridade, o primeiro da colaboração que depois prestaria à revista nos $2^{\circ}$ e $3^{\circ}$ ciclos.

\section{Caso de Gabriel Mariano: \\ O ciclo de Claridade ainda não terminou (em 1963)}

O paradigma "Centramento identitário VS Universalismo" não esgota o questionamento que vimos fazendo, que avança dois passos à luz das ideias produzidas por dois dos quatro intelectuais cabo-verdianos entrevistados por um jornal português no início da década de 1960 . Para Arnaldo França (1925-2015), a literatura cabo-verdiana havia evoluído ${ }^{\mathbf{1 2}}$ e, para Gabriel Mariano, o ciclo de Claridade ainda não havia terminado. ${ }^{\mathbf{1 3}}$

A evolução certifica-se, quer pelo surgimento da revista Certeza (da qual Arnaldo França fora o principal dinamizador), quer pela abertura registada pelos $2^{\circ} \mathrm{e}$ $3^{\circ}$ ciclos de Claridade. Por sua vez, a afirmação de que

12 Diário Popular, n 7417, 6/6/1963, Suplemento, n० 334 , pp. 1 e 7.

13 13 Diário Popular, no 7403, 25/5/1963, Suplemento, n० 332 , pp. 1, 8 e 15. 14 França, A. (1962). Notas sobre a Poesia e a Ficção Cabo-Verdianas. Praia: Centro de Informação e Turismo. o espírito da revista não se tinha encerrado à data daquelas entrevistas (1963) deve encontrar uma explicação plausível. A nação cabo-verdiana atingira um elevado grau de maturidade, vendo-se por outro lado merguIhada em problemas sociais e económicos que o regime colonial negligenciava ou não dispunha de meios para os solucionar. Nestas condições factuais, o temário de empenho identitário de Claridade (evidente no $1^{\circ}$ ciclo) simbolizava igualmente (ou simbolizou, desde sempre), um ideal de reacção (ideológica, mas não política, a nosso ver) que só terminaria com o acesso à soberania nacional (em 1975).

\section{Caso do protagonismo de Baltasar Lopes em Claridade: formas subtis de empenhamento}

No que concerne o papel de Baltasar Lopes na revista, retomamos a confissão de Arnaldo França que diz ter sido ele (B. Lopes) "o seu principal animador", 14 informação comedida de reconhecimento que convém verificar à luz dos dados empíricos espalhados por vários números.

Num balanço sobre a colaboração dos membros fundadores, pode-se imaginar quais eram as funções que na revista desempenhavam. Vistos os textos publicados e respectivas datas, é evidente que Baltasar Lopes/ Osvaldo Alcântara regista a mais elevada produção. A ele incumbia a função de organizador da colaboração e, além das notas e intervenções críticas, a versão em português de poemas em crioulo, bem como a 
produção de textos teóricos e culturais sobre as histórias publicadas do folclore tradicional oral.

Insistimos nestas tarefas para sublinharmos duas ou três ideias. Para lá da estratégia de abertura da revista à evolução, Claridade seria uma forma de "peça de convicção", com os conteúdos autóctones na poesia e na narrativa (em português), mas principalmente com os ensaios de linguística do crioulo, as poesias em crioulo, os contos de tradição oral e os estudos de etnografia a demonstrarem a pertinência cultural (e ideológica) do conceito de Cabo Verde cabo-verdiano, sem filiação vinculativa europeia ou africana.

Sabe-se que esta tese era, e continua a ser, o nó górdio de uma divergência de largo alcance ideológico que se resume em três teses: i) António Aurélio Gonçalves sustentava (como se viu) que a tradição literária cabo-verdiana, desde o romantismo, era um exemplo de abertura ao universalismo; ii) Nas décadas de 1930-1940, o português José Osório de Oliveira tentou fazer passar a tese de Cabo Verde como caso de regionalismo europeu; iii) Empenhado na contestação do regime colonial, alinhado com a política de Amílcar Cabral, líder da luta pela soberania de Cabo Verde, um grupo de intelectuais e de poetas insistia, e insiste, na tese oposta, de Cabo Verde como um caso de regionalismo africano.

\section{Oposição de termos irredutíveis}

No desiderato desta divergência, os campos demarcaram-se em torno da oposição entre as duas teses mais produtivas, "Cabo Verde cabo-verdiano VS Cabo Verde africano", sendo a segunda já bem perceptível cerca de 1947 nos tempos de pós-Guerra, com o avolumar das reacções soberanistas dos países do "Terceiro Mundo", das reivindicações dos patriotas da área africana e da política dinamizada pelas Nações Unidas contra as potências coloniais e, bem entendido, contra a obstinação colonial portuguesa.

Por saber literário se reconhece ser a poesia que, melhor do que a narrativa, se presta à veiculação de mensagens de desafio militante, de denúncia e de tomada de posição nos domínios ideológico e político. Esta circunstância explica a estratégia de Baltasar Lopes que, guardando o nome nas narrativas, cifrou a identidade sob o pseudónimo de Osvaldo Alcântara (pseudónimo não decifrado durante várias décadas) para se ocupar de temas de poesia de contestação do regime colonial. Mostra, no entanto, a sua leitura que, devido à elevada elaboração e refinado 
valor simbólico, a sua poesia estava destinada à perda de eficácia por atingir um horizonte muito reduzido de leitores (como ainda hoje).

Se o nível de elaboração dos seus poemas gerava um efeito de elitismo e se a função de reitor do Liceu lhe desaconselhava o recurso a um discurso poético mais audacioso, nada o impedia de atrair a colaboração de poetas de maior denodo militante, de leitura referencial inteiramente explícita e sem responsabilidades institucionais.

Apesar dessas reservas, não será por acaso que o n० 5 de Claridade tenha publicado, de Osvaldo Alcântara, o audacioso poema "Deslumbramento":

Tudo é estrela na minha prisão / O que eu não daria para saber / quem esteve semeando tantas fosforescências / neste terreno árido! / Quem me dera ser estereoscópio, / para disciplinar as minhas sensações / e assim escolher a minha oferenda / a esse deus desconhecido! / Milagre que desce não sei de onde... / Observo com olhos atónitos esta paisagem, / e tudo me arrepia e me estimula e me tempera. // Himalaias, crateras de bombas, / rictos de homens crispados de medo / vou libertar-me convosco, agonizar convosco, levantar as mãos ansiosamente convosco! / $\mathrm{E}$, no fim, colher o fruto desta nossa victória lenta / que vem marchando com passos silenciosos para mim há tantos séculos, / como prémio dos meus olhos bem abertos / para esta paisagem árida que me deslumbra... (Alcântara, 1986, p. 107).

Trata-se igualmente do número que incluiu pela primeira vez a colaboração de Aguinaldo Fonseca com os poemas "Metamorfose" e Oportunidade Perdida" (Fonseca, 1949, pp. 17 e 18), autor de conteúdos poéticos de referência imediata e dotados de grande poder mobilizador, como mostra o poema "Poeta e Povo":

O povo gritou fome. / Muitos ouviram e ninguém chorou. // O povo caiu na lama. / Todos o souberam mas ninguém chorou. // O povo martirizado / morreu em campos de concentração. / Ninguém chorou. // Mas o poeta escreveu então / o melhor poema de todos os poemas. // A voz do poema não era a voz do poeta: / era a voz do povo, o grito do povo, o choro do povo. // Os versos do poema choravam como o povo... / e o poeta ao escrevê-los, / chorava também com eles. (Fonseca, 1949, p. 28).

Por sua vez, sempre consequente nos domínios da política, Amílcar Cabral resumia num texto de apreciável concisão o percurso histórico da literatura cabo-verdiana que lhe permitia concluir com as seguintes recomendações: 
As mensagens da Claridade e da Certeza têm de ser transcendidas. O sonho de evasão, o desejo de "querer partir", não pode eternizar-se. O sonho tem de ser outro, e aos Poetas - os que continuam de mãos dadas com o Povo, de pés fincados na terra e participando no drama comum compete cantá-lo. Parece que António Nunes e Aguinaldo Fonseca estão na vanguarda dessa nova Poesia. [...] O primeiro, auscultando a terra e o Povo sonha com um "Amanhã" diferente [...] O segundo exprime, em toda a sua grandeza o "naufrágio em terra", do povo a que pertence (Cabral, 1952, p. 8).

Aparentemente, o texto presta-se ao papel de directiva programática, estabelecendo sugestões orientadoras dos novos poetas, táctica política de incitamento à preferência por temáticas em sintonia com a tese de Cabo Verde africano, no concerto da estratégia geral associada aos outros espaços de colonização portuguesa no continente africano.

\section{Claridade, empenho num contra-ataque}

Retomemos os dados. Uma vez reiniciado o $2^{\circ}$ ciclo de Claridade com o no 4 (1947), logo no no 5, ainda em 1947, Baltasar Lopes / Osvaldo Alcântara publicava "Deslumbramento" (entre outros poemas) e dois poemas do novo colaborador, Aguinaldo Fonseca, e depois, em continuidade, publicava deste poeta mais seis poemas, três no $n^{\circ} 6$ da revista, em 1948 , e outros três no seu n⿳ 7 , em 1949, sendo neste último conjunto que se inclui o transcrito poema "Poeta e Povo".

Atente-se naquilo que parece uma evidência em forma de jogo. Amílcar Cabral terá conhecido o "Poema de Amanhã", de António Nunes (residente em Lisboa e, pela mão de Teixeira de Sousa, introduzido no grupo neo-realista português), publicado em Certeza, no 2, de 1944, revista que considerou desactualizada. O encómio tecido a Aguinaldo Fonseca, exemplo de poeta comprometido, terá por certo resultado do conhecimento dele através de Claridade. Se forem sustentáveis estas deduções, pode-se aceitar que a inovação na poesia ideológica se antecipou na revista, visto que 1947 e 1949 precedem em 5 e 3 anos o texto de teor programático político de Amílcar Cabral, datado de 1952.

Suspensa pela segunda vez em 1949 e retomada em 1958, Claridade publica logo neste n० 8 , poemas de tema idêntico ao recomendado por Amílcar Cabral, de denúncia e de crítica social, disfarçadas por razões óbvias em dois poemas de Jorge Barbosa, em nove de Osvaldo Alcântara / Baltasar Lopes e em três de Arnaldo França, mas também sete poemas de enorme veemência perlocutória e teor revolucionário, três de Aguinaldo Fonseca, um de Onésimo Silveira e três de Ovídio Martins 
que, em um deles, emprega o modo enunciativo da oração prospectiva sobre a inevitabilidade dos tempos de mudança (tal como ocorre no poema "Deslumbramento" com o verso "Himalaias, crateras de bombas" e seguintes).

Entretanto, os jovens poetas agrupados no movimento "Nova Largada" identificado com aquela recomendação programática (de Amílcar Cabral) publicavam no "Suplemento Cultural" n० $1^{\mathbf{1 5}}$ um conjunto de textos constituído por três poemas de Aguinaldo Fonseca, três de Ovídio

15 Suplemento da revista Cabo Verde, Praia, Outubro, 1958. Martins, três de Yolanda Morazzo e um de Terêncio Anahory.

Fazendo fé nas datas, teria ocorrido, uma vez mais, uma jogada de antecipação. O "Suplemento Cultural" foi publicado cerca de cinco meses depois do no 8 de Claridade (Maio de 1958 / Outubro de 1958). Uma deriva não isenta de subjectividade motivada por noções histórico-literárias, leva-nos a admitir que a querela "Antigos VS Modernos" da década de 1930, no contexto de surgimento de Claridade, deve ser distinguida ponto por ponto do jogo e do dissídio que acabamos de descrever.

A função da querela consistiu em operar a ruptura necessária à transição entre duas estéticas, a do primeiro período literário, romântico (e clássico), já desgastado pela usura temporal, e a do segundo período literário, realista, que inaugurava a entrada na modernidade. Quanto aos jogos e ao dissídio, as questões também se elucidam pelo "apport" de teoria literária de orientação sociológica. Mostram as sugestões de Amílcar Cabral e a entrevista de Gabriel Mariano que os poetas intervinham diversamente animados pela motivação única da soberania, distintas questões de ética que, no domínio literário, se concretizam num fazer estético único (Lucien Goldmann), v.g., no mesmo sentido soberanista, se não houver contradição.

Ora, a despeito da unicidade estética (de ética patriótica), a teoria reconhece no seu interior uma larga variedade de poéticas em cena, segundo os temas, o léxico, os códigos discursivos e figurativos, os estilos, a força perlocutória, os referentes, v.g., conforme as gramáticas dominantes. Vale então admitir que a linha divisória entre as partes em querela e em dissídio é um epifenómeno de diversos protagonismos efémeros deveras produtivos. Considerando por junto essa sua diversidade, deles proveio um enorme enriquecimento do acervo literário cabo-verdiano. As querelas, os jogos, os dissídios e os não unanimismos têm essa inegável virtude criativa. 


\section{Para concluir: Jaime de Figueiredo, um intelectual "presencista"}

Façamos um recuo no tempo. Viu-se que, com João Lopes, Jaime de Figueiredo participou na dinamização do movimento Claridade tendo, por outro lado, tentado criar uma revista, Atlanta, no início da década de 1930, sem sucesso, para finalmente fazer parte do projecto Claridade e dele se ter afastado no último momento, sem sequer ter publicado o seu artigo para o primeiro número da revista.

O mistério deste corte radical tem perdurado até ao presente, jamais esclarecido de maneira convincente. A nosso ver, a elucidação de tal mistério muito ganhará se tomar por ponto de partida um dado fornecido pelo médico-escritor Teixeira de Sousa (1919-2006):

Com a "Presença" deu-se todavia, em Cabo Verde, um caso bastante curioso [...] Se a leitura da "Presença" preparou artisticamente o grupo que havia de fundar a revista "Claridade", não é menos exacto que a reacção dum Manuel Lopes, Jorge Barbosa, Baltasar Lopes, e outros, perante a vida, divergiu logo da mentalidade decadentista dos presencistas (Sousa, 1958, p. 12).

Sabe-se que Jaime de Figueiredo, artista muito dotado para o desenho, colaborou num Salão de pintura promovido pela Presença e identificava-se com a sua orientação estética e poética, evidentemente muito psicologista, como mostra um fragmento no início da sua análise de um poema de Osvaldo Alcântara:

Que maravilhoso convite ao devaneio íntimo, a música!

A música... que extraordinário poder de infiltração psíquica, de influxo espiritual exaltando os sentidos, ou arrebatando-os até à ascese da alma... Na pureza dos ritmos suaves, embaladores, cria momentos de intimismo, a calma propícia às expansões mais ternas; as notas profundas, graves, acompanham os transes mortais dos desesperos, os abismos da dor; vivem os acordes vibrantes e álacres a alegria e a vitória; o sonho enleia-se, sobe, imaterializa-se nos tons altos, fugitivos, dos violinos... (Figueiredo, 2017, p. 39). ${ }^{16}$

16 Figueiredo, J. (1956). “Ensaio de interpretação do poema 'Nocturno' de Osvaldo Alcântara". Cabo Verde, n. 78, Praia, pp. 6-18. [Republ. (2017). Jaime. Praia: Pedro Cardoso Livraria, pp. 39-54.]

Para situarmos a questão, lembremos que, em Portugal, nas décadas de 1930-1940, um conflito muito agressivo opunha as duas estéticas, a da "literatura viva" e da psicologia individual da Presença e a do neo-realismo de fiel inspiração marxista idanoviana, conflito que se repercutiu em Cabo Verde. Se à data do texto transcrito, 1956, Jaime de Figueiredo era ainda um intelectual presencista, psicologista, por maioria de razões o seria nos 
tempos de lançamento de Claridade. E à luz da transcrição de Teixeira de Sousa, ele seria para os companheiros uma personalidade brilhante, todavia decadente.

No estrito plano estético Jaime de Figueiredo identificava-se com os companheiros. Mas, na medida em que se descentrava no ideário poético, não poderia senão afastar-se deles. Por homologia contextual, a irredutível oposição entre presencistas e neo-realistas, em Portugal, equivaleria às desinteligências entre Jaime de Figueiredo e os companheiros de Claridade, sem conciliação possível.

\section{Resumindo}

Desde início, meados do século XIX, a história literária cabo-verdiana vem averbando um contínuo enriquecimento de conteúdos inevitavelmente realistas, até mesmo nos arroubos românticos, clássicos, simbolistas, parnasianos, sem deixar espaço para quaisquer derivas psicologistas ou individualistas.

Não há nenhum segredo nesse destino. O telurismo, o clima, a paisagem e a cintura do mar (António Aurélio Gonçalves) impõem-se a todas as formas de vida, seja ela rural ou urbana, popular ou refinada.

Impõem-se mas não determinam o que quer que seja. Estão sempre lá como pano de fundo que tudo condiciona, mesmo os sonhos, as fantasias ou os desejos que comandam a expressão literária. Assim mesmo, a nosso ver, parafraseando Jean-Pierre Allix (Allix, 1996). 


\section{Bibliografia}

AA.VV. (1944). Certeza. S. Vicente: Folha da Academia, n. 1; id., n. 2.

AA.VV. (2017). Claridosidade. Edição Crítica. Lisboa: Rosa de Porcelana.

AA.VV. (1959). Colóquios Cabo-Verdianos. Lisboa: Junta de Investigações do Ultramar.

AA.VV. (1958). "Suplemento Cultural" da revista Cabo Verde, n. 1, Praia: Imprensa Nacional

Alcântara, O. (1986). Cântico da Manhã Futura. Praia: Banco de Cabo Verde [Em publicação mais recente: (1991). id. Linda-a-Velha: ALAC].

Allix, J.-P. (1996). L'Espace humain. Paris: Seuil.

Amarilis, O. (1994). "Sobre a condição subalterna da mulher no mundo ocidental". Certeza, n. 1, S. Vicente, Março, p. 6.

Benveniste, É. (s.d.), "Estrutura das Relações de Pessoa no Verbo". O Homem na Linguagem. Lisboa: Vega, pp. 17-27.

Cabral, A. (1952). "Notas sobre a poesia caboverdeana". Cabo Verde, n. 28, Praia: Imprensa Nacional, pp. 5-8.

Cardoso, P. (1934). Sonetos e Redondilhas. Cabo Verde: Tip. Minerva.

Carreira, A. (1983). Cabo Verde - Formação e Extinção de uma Sociedade Escravocrata (1460-1878). s.I., ICL.

Carvalho, A. (2017). "Da Claridade, ainda, e sempre". AA.VV. Claridosidade. Lisboa: Rosa de Porcelana, pp. 17-39.

- (1997). “Um pouco de historiografia (Prefácio)". In Santos-Lopes, M. Falucho Ancorado. Lisboa: Cosmos, pp. XI-LXV

Conquet, J.-C. (1997). La Quête du Sens - Le langage en question. Paris: Presses Universitaires de France.

Duarte, M. (1954). “Caboverdianidade e Africanidade". Vértice, Vol. XIV, n. 134, Coimbra, pp. 639-644 [Republicado em Caboverdianidade e Africanidade e outros Textos. Praia: Spleen, 1999].

Ferreira, M. (org.) (1986). Claridade. Linda-a-Velha: ALAC.
Figueiredo, J. (1956). “Ensaio de interpretação do poema 'Nocturno' de Osvaldo Alcântara". Cabo Verde, n. 78, Praia, p. 6-18. [Republ. (2017). Jaime, Praia: Pedro Cardoso Livraria, pp. 39-54.]

Fonseca, A. (1949). "Metamorfose", "Oportunidade Perdida". Claridade, n. 5 pp. 17 e 18

- (1949). "Poeta e Povo". Claridade, n. 7, p. 28.

França, A. (1962). Notas sobre a Poesia e a Ficção Cabo-Verdianas. Praia: Centro de Informação e Turismo.

- (1963). Diário Popular, n. 7417, 6/6/1963 Suplemento, n. 334, pp. 1 e 7.

Goldmann, L. (1964). Pour une sociologie du roman. Paris: Gallimard.

Gonçalves, A. A. (1960). "Problemas da Literatura Romanesca em Cabo Verde". Antologia da ficção cabo-verdiana contemporânea. Praia: Edições Henriquinas Achamento de Cabo Verde.

Lopes, B. (1947). Chiquinho. S. Vicente Cabo Verde: Edições "Claridade"

- (1956). Cabo Verde Visto por Gilberto Freyre. Praia: Imprensa Nacional.

Lopes, B. et al. (Selecção, Introdução, Comentário). (1960). Antologia da Ficção Cabo-Verdiana Contemporânea. Praia: Edições Henriquina - Achamento de Cabo Verde.

Lopes, M. (1959). “Reflexões sobre a Literatura Cabo-Verdiana ou a Literatura nos Meios Pequenos". Colóquios Cabo-Verdianos. Lisboa: Junta de Investigações do Ultramar, pp. 3-22.

Silveira, O. (1963). Consciencialização na Literatura Caboverdiana. Lisboa: CEI (Casa dos Estudantes do Império).

Mariano, G. (1963). Diário Popular, n. 7417, 6/6/1963, Suplemento, n. 334, pp. 1 e 7.

Sousa, T. (1958). "Cabo Verde e a sua gente". Cabo Verde, n. 109, Praia, pp. 7-13.

Tynianov, I. (1965). "De l'évolution littéraire". Théorie de la littérature. Paris: Seuil, pp. 120-137. 